\title{
jC
}

Jurnal Civics: Media Kajian Kewarganegaraan

https://journal.uny.ac.id/index.php/civics/index

1829-5789 (print)

2541-1918 (online)

\section{Pembinaan karakter anak pada masyarakat perumahan di pinggiran kota}

\author{
Muhamad Abdul Roziq Asrori a,1* \\ a STKIP PGRI TULUNGAGUNG, Program Studi Pendidikan Pancasila dan Kewarganegaraan, \\ Tulungagung, Jawa Timur, Indonesia \\ ${ }^{1}$ roziq@stkippgritulungagung.ac.id \\ *korespondensi penulis
}

\begin{tabular}{ll}
\hline Informasi artikel & \\
\hline Sejarah artikel: & \\
Diterima & $: 13-07-2018$ \\
Revisi & $: 20-12-2018$ \\
Dipublikasikan & $: 31-03-2019$ \\
\hline
\end{tabular}

Kata kunci:

Karakter anak

Masyarakat kota

Teori role taking ABSTRAK

Penelitian ini bertujuan menjelaskan pembinaan karakter dan hambatan penyertaannya dilihat dari teori role taking pada masyarakat "Griya Kota“" Tulungagung. Metode penelitian menggunakan pendekatan kualitatif dengan jenis studi kasus. Proses pembinaan karakter dan moral anak pada tahap persiapan awal dilakukan dengan mengenalkan nilainilai agama sejak dini. Detail tahap perkembangan dan kebutuhan kesehatan anak untuk kesiapan membangun karakter sangat diperhatikan. Pada tahap play stage lebih selektif dalam memilih tayangan media dan juga teman bermain bagi anak. Sementara di tahap game stage, berupaya memberikan contoh baik terhadap anak dengan ucapan dan perilaku keseharian mereka serta menambah intensitas pengawasan meskipun tidak secara langsung untuk memastikan perkembangan anak. Pada tahap generalized others para orang tua lebih memberikan kepercayaan pada anak untuk mengembangkan kecakapan dengan dukungan fasilitas dan doa. Minimalisasi hambatan dibangun melalui komunikasi yang baik pada semua pihak dengan mengedepankan keguyuban warga melalui berbagai media, sekaligus menjadi teladan yang inspiratif.

Keywords:

Child character

Urban society

Role taking theory

\begin{abstract}
This study aims to explain the character building and the obstacles of viewers seen from the role-taking theory in the community "Griya Kota" Tulungagung. The research method used a qualitative approach with a case study type. The results showed the process of fostering the character and morals of children in the early preparation stage done by introduce religious values from an early age. Detailed stages of development and the health needs of children for the readiness to build character. In the play stage more selective in choosing media impressions and also playmates for children. While in the game stage, trying to provide good examples of children with their daily sayings and behaviors and increase the intensity of supervision, although not directly to ensure the development of children. At the stage of generalized others, the parents are more confident in the child to develop skills with the support of facilities and prayers. To minimize barriers built through with good communication on all sides in the same manner, as well as being an inspirational example.
\end{abstract}

\section{Copyright (C) 2019 Muhamad Abdul Roziq Asrori}

\section{Pendahuluan}

Pendidikan dalam keluarga memiliki nilai strategis dalam pembentukan karakter anak, sebab anak mengapresiasi sebagai undangan, bantuan, bimbingan, dan dorongan untuk pembinaan pengembangan diri sebagai pribadi yang berkarakter. Keluarga merupakan inspirator yang paling dekat bagi anak. Model hubungan keluarga antara orang tua dan anak memberikan stimulus bagi perkembangan kehidupan anak-anak (Crea \& Berzin, 2009), dan orang tua secara aktif membuat perencanaan bagi kehidupan keluarganya (Karpetis, 2017). Sejak kecil 
anak sudah mendapat dan berupaya menginternalisasi pendidikan dari orang tua melalui keteladanan dan kebiasaan hidup sehari-hari dalam keluarga. Bentuk keteladanan yang diberikan dan model kebiasaan hidup orang tua sehari-hari dalam keluarga menjadi role model perkembangan jiwa anak. Setiap hari orang tua dalam bersikap dan berperilaku tidak lepas dari perhatian dan pengamatan anak. Peran ayah dan ibu berkorelasi positif terhadap perkembangan anak dalam keluarga (Kim, Trahan, Bellamy, \& Hall, 2019; Pennell, Edwards, \& Burford, 2010). Ada tahap-tahap perkembangan yang harus dilalui oleh anak, mulai dari persiapan di lingkungan significant others sampai dirinya harus hidup pada lingkungan generalis others. Sementara anak adalah aktor yang selalu ingin meniru, dalam pendidikan dikenal dengan istilah anak belajar melalui imitasi.

Keberhasilan pendidikan bagi anak-anak dalam keluarga berdasarkan pada studi yang dilakukan pada empat negara di Asia Pasifik yang termasuk LMIC (Low and Middle Income Countries) menunjukkan hasil bawa peran orang tua menjadi role model pada Early Childhood Education (ECE) dan durasi orang tua bersama anak memberikan pengaruh signifikan bagi perkembangan positif anak (Rao, Richards, Sun, Weber, \& Sincovich, 2019). Pemerintahan di negara Asia Pasifik tersebut harus mendorong peran orang tua dalam menjalankan ECE tersebut (Rao et al., 2019). Sejalan dengan hal tersebut Mead menjelaskan dalam teori "role taking" bahwasanya anak berkembang dan memiliki kepribadian melalui beberapa tahapan mulai dari tahap menirukan peran orang-orang yang ada di sekitarnya sampai dia memasuki tahap penerimaan norma kolektif yang ada di dalam masyarakat, proses tersebut dilakukan melalui proses interaksi dan sosialisasi baik secara langsung maupun tidak langsung. Menguatkan pendapatnya Mead melalui teori "looking - glass self" Cooley mengungkapkan bahwa anak akan memiliki konsep diri (kepribadian) setelah ia melakukan interaksi sosial dengan masyarakat yang menghasilkan produk sosial (persepsi diri), dimana produk dari interaksi tersebut akan sangat tergantung pada inspirasi individu untuk memersepsikan dirinya untuk menampilkan perilakunya dalam masyarakat. Sementara inspirasi tersebut sangat berhubungan dengan hasil pengamatan dirinya pada orang-orang terdekatnya (significant others) dan pengalaman dirinya selama berinteraksi (Ritzer, 2010).

Melihat pentingnya peran orang tua yang bisa menginspirasi anak dalam membantu mengembangkan karakter pribadi dirinya, maka orang tua diharapkan bisa menjadi teladan yang baik pada anak-anaknya. Tidak hanya itu orang tua juga harus bisa menciptakan suasana yang bisa menggugah karakter kerja keras dan disiplin anak. Melalui kerja keras yang ditunjang dengan kedisiplinan diharapkan anak akan mampu tumbuh dan berkembang menjadi pribadi yang tangguh dan kuat guna menghadapi perkembangan zaman yang terus bergerak dan cepat terutama di era modernisasi dan globalisasi ini. Dengan demikian, anak-anak tidak terjebak pada kondisi yang Toffler (1989) disebut "future shock" (kejutan masa depan), yang seringkali membuat masyarakat bingung dalam menempatkan diri di kehidupan bermasyarakat. Terlebih pada masyarakat marginal.

Perumahan Griya Kota secara wilayah terletak di pinggiran Kota Tulungagung sehingga kehidupan masyarakatnya mengalami transformasi dari masyarakat desa ke masyarakat perkotaan. Tuntutan hidup pun sudah mulai mengalami peningkatan dalam segala bidang, sehingga membuat masyarakat harus semakin bekerja ekstra keras untuk bisa bertahan. Secara alamiah mereka yang bisa memanfaatkan peluang tentu yang bisa berkembang, baik secara ekonomi, sosial, maupun politik. Untuk itu guna mempersiapkan dan mengembangkan generasi mereka sebisa mungkin mereka harus memberikan pemodelan yang baik dan bisa dijadikan sebagai inspirasi positif untuk pengembangan karakter sang anak nantinya.

Selain hal tersebut masyarakat pada lingkungan perumahan memiliki keragaman yang tinggi dan cenderung individu. Menarik untuk diungkap bahwa perumahan tersebut secara unit bukan jenis perumahan dengan

70| Jurnal Civics: Media Kajian Kewarganegaraan 
jumlah kepala keluarga besar karena terdiri dari 38 unit dan diisi oleh 26 kepala keluarga. Sementara jika dilihat dari umur, masingmasing kepala keluarga mayoritas adalah keluarga yang relatif muda dengan anak usia rata-rata dibawah 8 tahun. Secara perilaku, pada usia muda keinginan untuk mendapatkan prestise relatif sangat tinggi. Keinginan untuk mengembangkan diri juga sangat kuat. Sementara tuntutan untuk membina karakter generasi penerus harus betul-betul diperhatikan, mengingat perkembangan teknologi dan informasi yang semakin pesat dan sulit dikontrol. Berdasarkan paparan tersebut perlu untuk mengangkat persoalan pembinaan karakter masyarakat perumahan Griya Kota yang bisa menjadi model inspiratif bagi masyarakat marginal.

Karakter mengandung tiga unsur pokok, yaitu mengetahui kebaikan (knowing the good), mencintai kebaikan (loving the good), dan melakukan kebaikan (doing the good) (Ryan \& Bohlin, 1999). Pendidikan karakter yang baik harus melibatkan pengetahuan yang baik (moral knowing), perasaan yang baik atau loving good (moral feeling) dan perilaku yang baik (moral action) sehingga terbentuk perwujudan kesatuan perilaku dan sikap hidup anak (Marzuki, 2008). Untuk mendapatkan hasil yang maksimal pembinaan karakter tidak bisa berjalan dengan instan tetapi butuh proses yang panjang.

Menurut Mead pengembangan diri manusia ini berlangsung melalui beberapa tahap-tahap play stage, tahap game stage, dan tahap generalized other (Ritzer, 2010). Menurut Mead setiap anggota baru masyarakat harus mempelajari peran-peran yang ada dalam masyarakat, suatu proses yang dinamakan pengambilan peran (role taking). Dalam proses ini seseorang belajar untuk mengetahui peran yang harus dijalankannya serta peran yang harus dijalankan orang lain. Melalui penguasaan peran yang ada dalam masyarakat ini seseorang dapat berinteraksi dengan orang lain.

Tahap pertama, play stage, seorang anak kecil mulai belajar mengambil peran orang yang berada di sekitarnya. Ia mulai menirukan peran yang di jalankan oleh orang tuanya, atau peran orang dewasa lain dengan siapa ia sering berinteraksi. Pada tahap tersebut anak belum sepenuhnya memahami isi peran-peran yang ditirunya itu. Tahap kedua, game stage, seorang anak tidak hanya telah mengetahui peran yang harus dijalankannya, tetapi telah pula mengetahui peran yang harus dijalankan oleh orang lain dengan siapa ia berinteraksi. Pada tahap ketiga, sosialisasi, seseorang dianggap telah mampu mengambil peranperan yang dijalankan orang lain dalam masyarakat, mampu mengambil peran generalized others. Anak telah mampu berinteraksi dengan orang lain dalam masyarakat karena telah memahami peranannya sendiri serta peran rang lain dengan siapa ia berinteraksi. Selaku anak, ia telah memahami peran yang dijalankan orang tua, selaku siswa ia memahami peran guru. Jika seseorang telah mencapai tahap ini maka menurut Mead orang tersebut telah mempunyai suatu diri. Dari pandanganpandangan Mead ini tampak jelas pendiriannya bahwa diri seseorang terbentuk melalui interaksi dengan orang lain (Ritzer, 2010).

\section{Metode}

Penelitian ini menggunakan pendekatan kualitatif dengan jenis penelitian studi kasus mengenai pembinaan karakter pada masyarakat perumahan Griya Kota Desa Tunggulsari Kecamatan Kedungwaru Tulungagung. Informan kunci ditentukan dengan menggunakan teknik purposive sampling dengan pertimbangan informan harus menguasai persoalan, dan menjadi pelaku dari fokus kajian. Karena pendekatan yang digunakan adalah kualitatif, maka instrumen utamanya adalah peneliti sendiri dengan menggunakan pedoman wawancara, observasi, dan dokumentasi.

Proses analisis data dilakukan secara kualitatif dengan pengumpulan data dilakukan di setiap akhir proses penelitian lapangan. Pengumpulan data dan analisisnya berproses dari upaya memperoleh informasi tentang banyak hal yakni, data lokasi yang terkait permasalahan penelitian, life history (riwayat hidup) kondisi sosial serta pekerjaan dari para 
informan yang berhubungan dengan fokus penelitian.

Selanjutnya, supaya data yang diperoleh mendapatkan derajat kepercayaan serta kepastian, maka dalam pengecekan keabsahan data tersebut digunakan teknik triangulasi sebagai teknik pemeriksaan yang memanfaatkan penggunaan sumber, metode, penyidik, dan teori (Creswell, 2012). Penelitian ini menggunakan triangulasi sumber sebagai teknik pengecekan keabsahan datanya.

\section{Hasil dan Pembahasan}

Pandangan Mead terkait pengembangan manusia berlangsung melalui beberapa tahapan, yaitu prepare, play, game stage, dan tahap generalized other. Teori ini memiliki asumsi bahwa pengembangan diri seseorang akan berlangsung melalui peranan yang diambil (role taking) pada setiap kali interaksi dengan orang lain. Sebelum memasuki dunia peranan orang lain, anak memiliki tahapan persiapan di lingkungan keluarga dan tempat dimana mereka tumbuh di awal. Pada tahap awal significant others memiliki peranan yang sangat penting karena menyangkut kesiapan anak kelak.

Pada tahap ini orang tua memiliki kesiapan yang beragam, lingkungan memiliki pengaruh yang signifikan terhadap pola pembentukan karakter anak pada tahap awal ini. Pemahaman orang tua terhadap pentingnya pendidikan keluarga memberikan warna yang tersendiri pada anak, terutama ketika anak memasuki dunia sosial ke depannya. Kecakapan sosial sangat tergantung bagaimana orang tua memulai konsep interaksi mereka dengan anakanaknya baik dalam kandungan maupun ketika sudah lahir. Shaffer, dkk. (Anapratiwi, Handayani, \& Kurniawati, 2013) menjelaskan bahwa kelekatan yang aman pada masa anakanak akan memprediksi kompetensi sosial di kemudian hari. Sementara itu kurangnya kelekatan yang aman menyebabkan kurangnya keterampilan sosial, yang terlihat dari kurang mampu menyelesaikan konflik interpersonal, kemampuan berkomunikasi dan lain-lain. Kualitas pengasuhan, lingkungan yang kondusif dan responsif memberikan stimulasi anak-anak agar mendorong perkembangan kognitif, sosial, dan emosional anak (Knauer, Ozer, Dow, \& Fernald, 2019).

Untuk kelekatan ini tampaknya beberapa warga Perumahan Griya Kota memahami dengan benar bagaimana mereka harus mengurus anak-anak mereka pada tahap perkembangan awal ini. Sejak dalam kandungan mereka telah memperhatikan detail kebutuhan yang harus mereka siapkan untuk kelangsungan anak-anak mereka kelak. Para orang tua memberikan kesan nuansa religious yang dibangun oleh masyarakat Griya Kota untuk mempersiapkan generasi penerus mereka sesuai dengan pemahaman nilai sosial yang mereka pahami. Orientasi mereka terhadap anak-anak adalah kecakapan moral individu berbasis agama.

Hasil pengamatan yang terlihat beberapa ibu menunggu anak-anak mereka ketika sedang mengaji sore hari di salah satu keluarga yang secara sukarela meluangkan waktunya untuk mengajarkan pendidikan agama kepada anak-anak Griya Kota. Sejak kecil mereka berupaya mendidik anak dengan baik dan disiplin. Hal tersebut sangat diperlukan mengingat keluarga adalah pendidik pertama bagi anak-anaknya. Di sini fungsi keluarga sebagai agen sosialisasi nilai dan norma harus dijalankan, dan warga masyarakat Griya Kota memulainya dengan baik.

Selain mempersiapkan psikis, mereka juga mempersiapkan diri anak pada kesiapan fisik mereka. Bahkan dengan adanya bidan yang menjadi salah satu penduduk Griya Kota menambah luas wawasan masyarakat. Perhatian yang lebih terhadap anak, memberikan kesan kedamaian kepada anak. Karena pada awal pertumbuhan ini anak berupaya mengenal orang-orang yang ada di sekitarnya, dan juga mengenal kehidupan di dunia ini. Kesan-kesan yang baik pastinya secara psikis membentuk kedamaian batin pada anak. Ditambahkan dengan kesehatan fisik mempercepat kesiapan anak untuk melangsungkan kehidupan mereka di dunia ini. Mempersiapkan anak secara psikis dan fisik membuktikan kedekatan orang tua kepada anak, meskipun kondisi mereka sibuk 
bekerja tetapi masih meluangkan waktu untuk mendekatkan diri pada anak.

Menurut (Anapratiwi et al., 2013) bahwa anak yang memiliki kelekatan aman pada ibu akan memiliki kemampuan sosialisasi yang baik, lebih mudah bersahabat, memiliki hubungan yang sehat, dan mudah beradaptasi dengan lingkungan sosial karena percaya lingkungan yang mereka tempati dapat memberikan kenyamanan dan keamanan.

Selain ibu, ayah juga memiliki peranan yang sangat penting dalam kehidupan anak. (Santrock, 2007) menjelaskan bahwa peran ayah selain sebagai pencari nafkah utama dan pembimbingan moral bagi remaja, ayah juga berperan dalam mengasuh anaknya. Sebagai pengasuh anak, ayah memegang peranan penting dalam penentuan status kelekatan anak, apakah anak akan membentuk kelekatan aman atau sebaliknya. Kelekatan antara ayah dan anak berhubungan dengan sikap dan perilaku ayah yang sensitif, bukan dengan jumlah waktu keterlibatan (Ekasari \& Bayani, 2009).

Kualitas kelekatan yang terjalin antara remaja dan ayah dapat memberikan pengaruh dalam kehidupan sosial. Interaksi dengan ayah yang mengasihi, mudah berkomunikasi, dan dapat diandalkan dapat memberikan kepercayaan dan keyakinan pada anak-anaknya sehingga akan mendukung perkembangan sosial. Peran ayah dalam sebuah penelitian di Eropa berkorelasi positif terhadap perkembangan anak dalam keluarga (Kim et al., 2019; Pennell et al., 2010)

Persiapan yang matang yang telah diberikan orang tua masyarakat Griya Kota untuk anak-anaknya diharapkan memberikan bekal positif terhadap perkembangan individu sehingga menjadi anak yang memiliki karakter yang baik, Lickona (2009) mengemukakan seseorang dikatakan memiliki karakter yang baik jika memenuhi komponen-komponen moral knowing, moral feeling, dan moral action, dan untuk menumbuhkan karakter yang baik diperlukan lingkungan yang baik.

Dari hasil data dan analisis tersebut bisa terlihat bahwa pada tahap awal perkembangan bayi, masyarakat perumahan griya kota telah mempersiapkan anak dengan mengenalkan nilai-nilai agama sejak dini melalui berbagai media baik audio maupun visual dengan konten religious, sekaligus memperhatikan detail tahap perkembangan dan kebutuhan kesehatan anak untuk kesiapan membangun karakter.

Tahap lanjut dari preparatory stage adalah play stage. Pada tahap ini anak-anak mulai belajar mengambil peranan orang-orang yang berada di sekitarnya. Pada saat ini seorang anak biasanya meniru tingkah laku orang lain. Seperti bermain dengan meniru peran yang dijalankan ayah, ibu, dokter, atau polisi. Kemungkinan peran yang ditiru tergantung dengan peran apa yang paling sering dilihatnya. Meskipun mereka menirukan apa yang dilakukan, tetapi mereka tidak memahami sepenuhnya untuk apa orang yang mereka tiru perannya melakukan hal tersebut. Seperti ketika dari mereka menirukan ayahnya yang pergi untuk berangkat kerja, maka mereka tidak paham untuk apa ayahnya pergi berkerja dan makna lainnya dibalik hal tersebut.

Pada tahap ini hasil wawancara dengan beberapa keluarga mendapatkan gambaran, bahwa pola peniruan yang dilakukan oleh anak-anak sangat beragam sesuai dengan visualisasi yang sering dia dapatkan. Orang tua menjadi sisi yang sangat berpengaruh dan juga media massa yang sering anak lihat. Untuk memagari peniruan yang kurang produktif beberapa keluarga membiasakan anak-anak mereka untuk melihat tokoh yang baik dari orang tuanya. Mereka menganggap orang tua adalah tokoh terbaik yang biasanya dijadikan idola oleh anak secara nyata.

Selama observasi pada pola perilaku anak-anak usia play stage di perumahan Griya Kota, terlihat setiap sore ada beberapa keluarga yang rutin berjamaah di musala dekat perumahan. Mereka membonceng anakanak untuk ikut berjamaah. Rutinitas tersebut terlihat pada salat Asar dan Magrib. Selain itu tampilan fisik yang diperlihatkan oleh anakanak hampir mirip dengan ibu mereka, karena lebih anak-anak perempuan jumlah lebih banyak dari laki-laki. Tetapi dari mayoritas dampak media massa dari pemutaran film karton memberikan pemodelan yang 
signifikan, seperti tata bahasa yang digunakan mirip-mirip dengan bahasa dari film Ipin dan Upin dan model baju yang dipilih oleh anakanak banyak bernuansa karton yang bermotif karton Kuda Pony atau pun Princes.

Dalam pandangan Mead pada tahap play stage ini, orang tua harus memerankan fungsi keluarga dengan baik, karena mereka adalah significant others bagi anak-anak. Sementara anak adalah aktor yang terbaik dalam berimitasi (Asrori, 2013). Perkembangan anak dengan tahapan yang baik pastinya mampu memberikan pembinaan karakter yang maksimal. Fungsi keluarga sebagai tempat kasih sayang dan wahana pendidikan awal bagi anak harus diberikan secara maksimal untuk membantu mempercepat tumbuhnya rasa percaya diri dan kenyamanan hidup bagi anak.

Dari hasil data dan analisis data bisa disimpulkan bahwa media massa memberikan dampak pada anak-anak seperti gaya bicara, pilihan kosakata, tindakan dan pola pikirnya, sehingga menjadikan beberapa orang tua selektif dalam memilih tayangan dan juga teman bermain bagi anak. Menyadari anak sedang senang meniru, mayoritas berupaya untuk memberikan percontohan yang baik terhadap anak dengan ucapan dan perilaku keseharian mereka

Menurut Mead seseorang dapat dinyatakan dapat mengambil peranan orang lain dengan menjalankan peran-peran yang ada di sekitarnya. Nilai-nilai dari interaksi yang dijalankan lama-lama akan membentuk jaringan pengetahuan dirinya, dan kemudian mendorongnya untuk menjalankan nilai tersebut dalam sebuah interaksi sosial. Nilainilai yang telah terinternalisasi ke dalam diri membentuk karakter khas individu dalam interaksi sosialnya.

Mayoritas masyarakat Griya Kota mengalami kesulitan dalam mengontrol anak pada tahap game stage. Pada tahap ini pengalaman anak sudah bertambah luas seiring dengan meluasnya tingkat jaringan interaksi yang dialami oleh individu. Sehingga pengalaman dan pemahaman akan dunia ini membentuk keinginan untuk semakin ingin mengetahui banyak hal. Peer group yang dimiliki menambah kuat polarisasi perilaku anak sesuai dengan pengutaraan pengalaman masing-masing. Interaksi yang makin intensif dikalangan peer group membentuk pengalaman baru anakanak dan mulai membandingkan dengan pengalaman di keluarga masing-masing.

Hasil pengamatan anak-anak Griya Kota sudah membaur satu sama lain, meskipun perumahan ini masih terbilang baru. Bahkan tidak hanya mereka yang berada pada kawasan perumahan, tetapi juga dengan anakanak sekitar perumahan Griya Kota. Terlebih memang ketika musim bermain yang mengasyikkan bagi anak-anak seperti bermain layang-layang, kelereng, bahkan sering juga mereka memancing bersama di sungai dekat perumahan.

Dunia bermain memang sangat mengasyikkan bagi anak-anak. Masa-masa bermain memberikan nuansa baru bagi anakanak ketika selama ini hanya menemukan orang-orang yang tidak banyak jumlahnya. Teman-teman baru bagi anak menambah pengetahuan baru, sekaligus pengalaman baru. Nilai-nilai yang selama ini didapatkan di keluarga bisa semakin dalam mereka terapkan dalam dunia bermain mereka.

Dari hasil data tersebut bisa disimpulkan bahwa aktivitas bermain anak-anak yang mulai beragam memberikan kecemasan pada orang tua, sehingga menambah intensitas pengawasan meskipun tidak secara langsung untuk memastikan perkembangan anak.

Tahapan ketiga disebut dengan tahapan generalized others. Tahapan individu dapat berinteraksi karena telah mampu untuk memahami perannya sendiri serta peranan orang lain yang berinteraksi dengannya. Seorang anak dapat memahami perannya sebagai anak dari orang tuanya di rumah dan sebagai murid ia mampu memahami peran seorang guru yang berinteraksi di sekolah dengannya. Pada tahapan ini seseorang mempunyai suatu diri, secara tidak langsung dapat disimpulkan bahwa Mead memaparkan bahwa diri seseorang terbentuk dari interaksi dengan orang lain.

Perkembangan karakter anak-anak Perumahan Griya Kota dilihat dari perspektif Mead tersebut mengalami percepatan yang sangat signifikan. Remaja perumahan ini 
memiliki karakter yang tidak jauh dari lingkungan keluarga, meskipun secara lingkungan mereka memiliki pola yang sedikit berbeda. Hal tersebut karena lingkungan perumahan baru terbentuk dengan masa yang pendek. Nilai-nilai sosial yang terbentuk dari kebersamaan mereka belum banyak terbentuk. Sehingga mereka tumbuh dengan berbagai nilai tempat asal selama ini, ditambahkan dengan lingkungan pendidikan yang mereka dapatkan.

Mayoritas hasil pengamatan terhadap remaja warga Perumahan Griya Kota memiliki kemandirian yang baik, bahkan cara pandang mereka terhadap hidup mereka terbilang sudah cukup matang. Secara umum mereka lebih terbuka dalam pergaulan, dengan etika norma yang masih sesuai jalur tatanan yang diharapkan oleh keluarga mereka. Pendidikan yang mereka tempuh lebih bervariasi dengan kepentingan ke arah jenjang kerja paska mereka menyelesaikan studi mereka.

Kedewasaan anak-anak memberikan kepercayaan pada orang tua untuk mengembangkan kecakapan mereka dengan memberikan dukungan fasilitas dan doa. Pada teori role taking yang dikembangkan oleh Mead ini, perkembangan individu sangat ditentukan oleh agen-agen terlibat dalam interaksi sosial anak selama ini. Agen tersebut setiap stage punya peran masingmasing yang siap diadopsi oleh individu, seperti keluarga, teman bermain, sekolah, dan media massa. Pada keluarga biasanya yang masuk dalam ruang lingkup utamanya adalah orang tua dan saudara kandung, meskipun begitu terjadi kecenderungan bergesernya agen sosialisasi yang utama ini. Contohnya di kota besar banyak orang tua dengan mobilitas tinggi sehingga menitipkan anak pada pembantu. Sehingga pembantu memerankan peranan penting sebagai agen sosialisasi. Agen sosialisasi yang menjembatani anak masuk ke tahapan play stage. Dalam kasus ini, warga perumahan Griya Kota tidak terlalu mengalami pergeseran, meskipun banyak dari mereka juga termasuk keluarga sibuk tetapi masih bisa meluangkan waktu untuk keluarga, minimal jika mereka terlalu sibuk ada kakek dan neneknya yang menggantikan peran orang tua sehingga tidak terlalu jauh rentangnya karena masih memiliki kesamaan pola.

Selain itu agen teman bermain merupakan agen sosialisasi selanjutnya. Biasanya yang termasuk agen ini adalah teman sekolah, tetangga, atau keluarga yang hubungannya tidak setingkat (orang tua-anak, paman-keponakan, atau kakek-cucu). Pada agen sosialisasi ini anak mempelajari kemampuan baru. Pada agen sosialisasi ini anak memasuki tahapan game stage. Agen sosialisasi berikutnya adalah sistem pendidikan, yang biasanya lebih erat kaitannya dengan sistem pendidikan formal, yaitu sekolah. Selain dari pelajaran yang dipelajari, sekolah mengajarkan hal lain yang tidak diajarkan agen-agen sosialisasi sebelumnya. Sekolah mengajarkan kemandirian, prestasi, dan universalisme. Banyak hal yang dapat membawa anak kepada pengajaran meskipun secara tidak langsung seperti ranking kompetensi di kelas, keharusan mengerjakan pekerjaan rumah sendiri, perlakuan sama yang ia dapat di sekolah, dan keanekaragaman mata pelajaran yang ada.

Agen sosialisasi selanjutnya adalah media massa, yang termasuk kategori media massa adalah media cetak (surat kabar, majalah) maupun media elektronik (radio, televisi, video, film, kaset, CD). Perlu ditambahkan media elektronik yang terkini dan mengalami perkembangan, yaitu internet. Media massa merupakan agen sosialisasi yang mampu menghimpun dan menginformasikan ke banyak orang untuk satu informasi. Di sini agen sosialisasi keluarga berperan penting dalam memberikan pengawasan. Agar anak dapat belajar menyaring informasi yang didapatkan. Informasi yang ada di media massa tidak semua harus dan bisa dikonsumsi oleh publik terutama anak-anak. Terlebih di masa sekarang media massa yang mengalami percepatan informasi yang luar biasa dan bisa diakses oleh siapa saja dan dimana saja.

Pembentukan karakter butuh proses yang lama dan strategi yang tepat untuk melakukannya. Selain itu berbagai faktor juga turut melatarbelakangi keberhasilan pembinaan karakter, seperti lingkungan 
keluarga, teman bermain, sekolah dan masyarakat dimana mereka berada terlebih juga adalah media massa yang sekarang tidak bisa lagi dibatasi. Agen-agen tersebut memberikan identitas bagi anak, karena dari mereka anak belajar mengimitasi dan mengidentifikasi sehingga keterampilan sosial bisa terbentuk dengan baik atau lebih suka dikenal dengan karakter khas individu.

Keterampilan sosial harus dikembangkan sejak dini karena anak yang dapat melakukan hubungan sosial secara baik dengan lingkungannya akan memiliki dasar dan mempunyai kemampuan untuk meraih keberhasilan di masa yang akan datang. Keterampilan sosial perlu dikembangkan sejak dini untuk mencegah kegagalan dan kesulitan di masa sekolah dan masa dewasa kelak (Cartledge \& Kiarei, 2001). Sejalan dengan itu bahwa keterampilan sosial siswa yang dimiliki individu berfungsi untuk mengatasi permasalahan-permasalahan yang timbul akibat dari berinteraksi.

Menurut Moeslichatoen (2014), bentuk keterampilan sosial anak di taman kanakkanak yang harus dikuasai dalam memenuhi tugas-tugas perkembangan berikutnya sehingga dapat berkembang secara sehat dan normal, antara lain: membina dan menanggapi hubungan antar pribadi dengan anak lain secara memuaskan, tidak suka bertengkar, tidak ingin menang sendiri, berbagi makanan ringan dan mainan, dan sering membantu. Akan tetapi tidak semua anak mampu menguasai bentuk keterampilan sosial dalam bersosialisasi.

Dalam hal ini, Nurihsan \& Agustin (2011) menjelaskan beberapa masalah sosial yang sering dialami anak adalah: anak ingin menang sendiri, sok berkuasa, tidak mau menunggu giliran bila bermain bersama, selalu ingin diperhatikan atau memilih-milih teman, agresif dengan cara menyerang orang atau anak lain, merebut mainan atau barang orang lain, merusak barang teman lain dan ketidakmampuan menyesuaikan dengan lingkungan baru.

Rendahnya keterampilan sosial ini membuat anak kurang mampu menjalin interaksi secara efektif dengan lingkungannya dan memilih tindakan agresif sebagai strategi coping (Cartledge \& Kiarei, 2001). Mereka cenderung menganggap tindakan agresif merupakan cara yang paling tepat untuk mengatasi permasalahan sosial dan mendapatkan apa yang mereka inginkan. Akibatnya, mereka sering ditolak oleh orang tua, teman sebaya dan lingkungan.

Dalam menyelesaikan masalah pembinaan karakter masyarakat perumahan Griya Kota memiliki langkah-langkah yang komunikatif. Perlu langkah-langkah bersama dalam membangun karakter anak-anak, karena mereka berada dalam satu kawasan dengan satu pintu. Butuh media komunikasi yang jelas dan cepat. Hal tersebut bisa dibangun melaui grup-group sosial media, seperti WhatsApp atau yang lainnya dengan komunikasi yang baik dengan memanfaatkan group media sosial untuk membahas isu perkembangan seputar perumahan

Strategi lain yakni pemodelan bagi anakanak dengan membangun lingkungan yang religious. Lingkungan masyarakat sangat menentukan perkembangan karakter moral anak. Lingkungan tempat tinggal merupakan wahana tempat menggembleng diri secara langsung dan aplikatif. Untuk itu bangunan lingkungan yang baik mencerminkan kepribadian lingkungan.

Untuk mengatasi berbagai masalah bagi keluarga dalam mendidik anak-anak, responden lebih suka menggunakan istilah inspirasi. Untuk mengatasi hambatan yang muncul dalam proses penanaman karakter mereka perlu menginspirasi nilai-nilai yang positif pada anak-anak mereka. Untuk memberikan inspirasi bisa dilakukan dengan beberapa teknik, yaitu seperti (1), menjadi cermin yang baik untuk anak (Asrori, 2013). Ketika masih kecil anak cenderung menggunakan perasaan ketimbang logika. Baru ketika beranjak dewasa mereka mulai menggunakan logikanya dalam berpikir. Kalau sejak kecil orang tua sudah memberi contoh perilaku kasar pada anaknya, maka jangan salahkan kalau anak akan menjadi pribadi yang kasar juga. Akan tetapi lain halnya kalau menerapkan kelembutan, maka anak pun akan menjadi pribadi yang baik pula.

Dengan memosisikan diri sebagai cermin dan anak sebagai orang yang sedang 
bercermin, sangat memungkinkan sang buah hati mengikuti apa yang dilihat oleh mata mereka dan apa yang mereka rasa ketika harus mengalaminya. Membiasakan diri menjadi cerminan baik untuk anak-anak secara tidak langsung telah memberikan inspirasi yang baik untuk anak-anak. Sebagaimana yang dikatakan oleh Mead bahwasanya anak adalah aktor yang terbaik dalam berimitasi dan kepribadian anak tumbuh lewat proses imitasi dalam interaksi sosialnya bersama significant others maupun generalized others (Ritzer, 2010)

Selanjutnya dilakukan dengan cara (2), menjadi sosok teman yang menggembirakan untuk anak. Mengaburkan batas senioritas sejak dini bisa menumbuhkan rasa nyaman bagi anak. Para orang tua yang memosisikan diri sebagai teman yang menggembirakan bagi anak memunculkan suasana komunikatif dalam keluarga. Sehingga di saat anak mendapatkan kesulitan dan butuh tempat mengadu, maka orang tua merupakan orang pertama yang dicari anak untuk dimintai nasihat dan bimbingan dalam menyelesaikan permasalahan. Seperti masalah yang didapat di sekolah maupun ketika bermain dengan teman sebaya.

Dengan menjadi teman tersebut sekaligus orang tua bisa mengontrol perkembangan anak. Sebab anak terbiasa menceritakan yang telah dilakukan baik dalam pengawasan maupun di luar pengawasan orang tua. Sehingga ketika mendapati anak sudah mulai keluar dari tatanan nilai maka orang tua langsung bisa memberikan pengarahan dan bimbingan yang baik buat anak. Ataupun sebaliknya ketika anak mendapatkan sebuah prestasi bisa memberikan dorongan untuk semakin meningkatkan potensinya.

Sosok teman yang menggembirakan memberikan nuansa positif bagi perkembangan anak. Terutama dalam internalisasi nilai karakter bagi anak, sebab pembiasaan yang berlangsung setiap hari merupakan pendidikan yang diterima oleh anak dan memberikan inspirasi-inspirasi untuk pengembangan karakter dan potensi ke depan. Sekaligus menjadi fondasi yang kukuh untuk masa depan anak dalam kehidupan bermasyarakat kelak. Menjadi teman yang menggembirakan bagi anak berarti fungsi keluarga sebagai tempat perlindungan dan sosialisasi serta pendidikan telah berjalan dengan baik. Nuansa demokratis yang ditunjukkan memberikan kehangatan cinta kasih dalam keluarga yang bisa mempercepat pengembangan kepercayaan diri dan kematangan karakter dan kepribadian terutama disiplin dan kreativitas anak. Sebagaimana yang diungkapkan oleh (Gunarsa, 1991) bahwa pola demokratis yang dikembangkan dalam keluarga mendorong anak untuk mampu berdiri sendiri, bertanggung jawab dan yakin terhadap diri sendiri serta daya kreativitasnya berkembang baik karena orang tua selalu merangsang anaknya untuk mampu berinisiatif.

Langkah yang selanjutnya (3), menjadi motivator yang inspiratif bagi anak. Fungsi keluarga di antaranya adalah memberikan sosialisasi dan pendidikan yang terbaik pada anggota keluarganya. Harapannya setiap generasi mampu mengembangkan dan memaksimalkan potensi yang ada pada diri sesuai dengan nilai dan norma masyarakat serta perkembangan zaman.

Dengan menceritakan kisah dan pengalaman yang baik secara tidak langsung dapat menginternalisasi ketokohan orang tuanya yang memiliki kedisiplinan dan kreativitas dalam kehidupan mereka. Tokoh yang sudah melekat kuat di dalam diri anak tersebut mampu menjadi inspirasi anak dalam menjalankan aktivitas sehari-hari. Semakin kuat tertanam semakin kuat inspirasi yang dihasilkan.

Prinsip inspirasi tersebut sejalan dengan pemikiran tokoh pendidikan $\mathrm{Ki}$ Hajar Dewantara yang dijadikan filosofi pendidikan di Indonesia yaitu ing ngarso sung tulodo, ing madyo mangon karso, tutwuri handayani. Para orang tua tersebut ketika menginginkan anak-anak mereka tumbuh dengan karakter pribadi yang baik, maka mereka memberikan keteladanan yang baik, dan siap menjadi orang pertama yang akan dicari sang anak untuk berkeluh kesah ketika mendapatkan masalah. Sekaligus mampu membimbing dan memberikan semangat pada anak-anak mereka untuk mencapai cita-cita yang mereka inginkan (Asrori, 2017). 
Dari analisis data tersebut bisa disimpulkan bahwa untuk mengatasi berbagai persoalan yang memperlambat proses pembinaan moral masyarakat griya kota membangun komunikasi yang baik pada semua pihak dengan mengedepankan keguyuban warga melalui berbagai media sekaligus menjadi teladan dan inspiratif.

\section{Simpulan}

Proses pembinaan moral anak yang dilakukan oleh masyarakat Griya Kota pada tahap persiapan awal dilakukan dengan mengenalkan nilai-nilai agama sejak dini melalui berbagai media baik audio maupun visual dengan konten religious, sekaligus memperhatikan detail tahap perkembangan dan kebutuhan kesehatan anak untuk kesiapan membangun karakter. Pada tahap play stage media massa yang dikonsumsi oleh anak-anak memberikan pengaruh pola perilaku seperti gaya bicara, pilihan kosakata, beserta tindakan sehingga menjadikan beberapa orang tua selektif dalam memilih tayangan dan juga teman bermain bagi anak. Menyadari anak sedang senang meniru, mayoritas berupaya untuk memberikan percontohan yang baik terhadap anak dengan ucapan dan perilaku keseharian mereka. Aktivitas bermain anakanak yang mulai beragam memberikan kecemasan pada orang tua, sehingga menambah intensitas pengawasan secara tidak langsung, hal itu untuk memastikan perkembangan anak. Bagi anak-anak remaja mereka yang sudah siap menerima nilai masyarakat secara umum mereka lebih memberikan kepercayaan pada anak untuk mengembangkan kecakapan mereka dengan memberikan dukungan fasilitas dan doa. Untuk mengatasi berbagai persoalan yang memperlambat proses pembinaan moral masyarakat griya kota membangun komunikasi yang baik pada semua pihak dengan mengedepankan keguyuban warga melalui berbagai media sekaligus menjadi teladan yang mampu memberikan inspirasi positif bagi anak

\section{Ucapan Terima Kasih}

Penelitian ini di danai sepenuhnya oleh Lembaga STKIP PGRI Tulungagung. Peneliti mengucapkan terima kasih yang sebesarbesarnya. Begitu juga kami sampaikan terima kasih kepada warga perumahan Griya Kota dan seluruh pihak yang terkait dengan penelitian ini.

\section{Referensi}

Anapratiwi, D., Handayani, D. S. S., \& Kurniawati, Y. (2013). Hubungan antara kelekatan anak pada ibu dengan kemampuan sosialisasi anak usia 4-5 tahun (Studi Pada RA Sinar Pelangi dan RA Al Iman Kecamatan Gunung Pati, Semarang). Semarang: Early Childhood Education Papers (Belia).

Asrori, M. A. R. (2013). Orang tua inspiratif. Inspirasi Jurnal Ilmiah Ilmu social STKIP PGRI Tulungagung, 8(16).

Asrori, M. A. R. (2017). Perwujudan nilainilai strategis revolusi mental pendidikan pada kearifan lokal pesantren. Jurnal Civics, 14(1), 23-32.

Cartledge, G., \& Kiarei, M. W. (2001). Learning social skills through literature for children and adolescent. Teaching Exceptional Children Journal, 34, 4047.

Crea, T. M., \& Berzin, S. C. (2009). Family involvement in child welfare decisionmaking: Strategies and research on inclusive practices. Journal of Public Child Welfare, 3(3), 305-327.

Creswell, J. W. (2012). Educational research: planning, conducting and evaluating quantitative and qualitative research. Boston: Pearson.

Ekasari, A., \& Bayani, I. (2009). Attachment pada ayah dan penerimaan peer group dengan resiliensi (Studi kasus pada siswa laki-laki di tingkat sekolah menengah Pertama). Journal Soul, 2(2).

Gunarsa, S. D. (1991). Psikologi praktis anak, remaja dan keluarga. Jakarta: Gunung Mulia.

Karpetis, G. (2017). Theories on child protection work with parents: A narrative review of the literature. Child welfare, 95(2). 
Kim, J., Trahan, M., Bellamy, J., \& Hall, J. A. (2019). Advancing the innovation of family meeting models: The role of teamwork and parent engagement in improving permanency. Children and Youth Services Review, 100(November 2018), 147-155. https://doi.org/10.1016/j.childyouth.201 9.02.039

Knauer, H. A., Ozer, E. J., Dow, W. H., \& Fernald, L. C. H. (2019). Parenting quality at two developmental periods in early childhood and their association with child development. Early Childhood Research Quarterly, 47, 396404.

https://doi.org/10.1016/j.ecresq.2018.08. 009

Lickona, T. (2009). Educating for character: How our schools can teach respect and responsibility. New York: Bantam Books.

Marzuki. (2008). Meneladani Nabi Muhammad SAW dalam kehidupan sehari-hari. Jurnal Humanika, 8(1), 7587.

Moeslichatoen. (2014). Metode pengajaran di taman kanak-kanak. Jakarta: Rineka Cipta.

Nurihsan, A. J., \& Agustin. (2011). Dinamika perkembangan anak dan remaja (tinjauan Psikologi Pendidikan dan bimbingan). Bandung: Refika Aditama.

Pennell, J., Edwards, M., \& Burford, G. (2010). Expedited family group engagement and child permanency. Children and Youth Services Review, 32(7), 1012-1019. https://doi.org/10.1016/j.childyouth.201 0.03 .029

Rao, N., Richards, B., Sun, J., Weber, A., \& Sincovich, A. (2019). Early childhood education and child development in four countries in East Asia and the Pacific. Early Childhood Research Quarterly, 47 , 169-181. https://doi.org/10.1016/j.ecresq.2018.08. 011

Ritzer, G. D. J. G. (2010). Modern sociological theory. Jakarta: Prenada Media.

Ryan, K., \& Bohlin, K. E. (1999). Building character in schools: Practical ways to bring moral instruction to life. San Francisco, CA: Jossey-Bass Inc., Publishers.

Santrock, J. W. (2007). Remaja (11 ed.). Jakarta: Erlangga.

Toffler, A. (1989). Future shock (Kejutan masa depan), Terj. (S. Koesdiyantinah, Penerj.). Jakarta: Pantja Simpati. 